\title{
STRATEGI MENCAPAI KEBERMAKNAAN PEMBELAJARAN BAHASA ARAB PADA ANAK USIA DINI
}

\author{
Nginayatul Khasanah* \\ IAINU Kebumen \\ nginayatulkh@gmail.com \\ *Penulis koresponden
}

\begin{tabular}{|l|l|l|}
\hline Diajukan: 18-05-2021 & Diterima: 25-05-2021 & Diterbitkan: 12-06-2021
\end{tabular}

\begin{abstract}
Early childhood is called the golden age in the growing period of the child. Early childhood means children aged o-6 years. At this time children growth rapidly and through the learning process, one of them was language learning as a means of communication. Arabic languange for Indonesian children is a foreign language so there found are various problems. That problems is the meaningless of arabic learning for children. So kindergarten and TPA / TPQ as institutions of early childhood education play an important role in implementing strategies learning. Meaningful Arabic learning for early childhood can be achieved by implementing the right strategy, including the selection materials, media and methods according to the early childhood development stage such as learning while playing. It is based on Carl Rogers and David Ausubel's theory of meaningful learning.
\end{abstract}

Keywords: Meaningful learning strategies, Arabic learning, early childhood

Abstrak: Usia dini merupakan fase keemasan dalam tumbuh kembang anak. Anak usia dini yang dimaksud adalah anak berumur o-6 tahun. Pada masa ini anak mengalami pertumbuhan pesat dan melalui proses belajar salah satunya belajar bahasa sebagai sarana komunikasi dan bahasa agama. Bahasa Arab bagi anak Indonesia merupakan bahasa asing sehingga dalam pembelajarannya dijumpai berbagai problematika. Problematika tersebut diantaranya kurang bermaknanya pembelajaran bahasa Arab bagi anak. Maka TK dan TPA sebagai lembaga pendidikan anak usia dini berperan penting dalam penerapan strategi pembelajaran. Kebermaknaan pembelajaran bahasa arab anak usia dini bisa dicapai dengan penerapan strategi diantara dengan pemilihan materi, media, dan metode yang tepat sesuai dengan tahap perkembangan anak usia dini yaitu belajar sambil bermain dan menyenangkan. Hal tersebut mengacu pada teori belajar bermakna Carl Rogers dan David Ausubel.

Kata kunci: Strategi Kebermaknaan Pembelajaran, Pembelajaran Bahasa Arab, Anak Usia Dini 


\section{A. Pendahuluan}

Belajar merupakan proses manusia untuk mencapai berbagai macam kompetensi, keterampilan, dan sikap. Melalui belajar seseorang akan mendapatkan pengalaman dan ilmu. Belajar dimulai sejak manusia lahir sampai akhir hayat. ${ }^{1}$ Dengan demikian belajar tidaklah mengenal waktu. Akan tetapi belajar di usia dini mempunyai keistimewaan tersendiri yang sering dianalogikan bagaikan mengukir di atas batu

Anak Usia dini yang dimaksud dalam penelitian ini adalah anak usia 0-6 tahun sebagaimana yang dinyatakan dalam Peraturan Presiden (Perpres) Nomor 6o Tahun 2013, bahwa anak usia dini adalah bayi yang baru lahir hingga anak-anak yang belum genap berusia 6 tahun. Kaitannya dengan pendidikan, usia dini ini merupakan masa keemasan atau golden age. ${ }^{2}$ Pada usia dini ini, terjadi pertumbuhan dan perkembangan baik jasmani, rohani, psikis motorik, maupun kognitif sehingga anak cepat menerima rangsangan atau stimulus. Diantara stimulus tersebut berupa perilaku dan tutur kata (bahasa). Stimulus bahasa pada anak disebut dengan pemerolehan bahasa pertama/bahasa Ibu. ${ }^{3}$

Setelah seorang anak memperoleh bahasa pertamanya, anak itu akan mengalami proses pemerolehan bahasa kedua melalui apa yang disebut dengan pembelajaran bahasa. Pembahasan ini ada yang menyebut dengan istilah pembelajaran bahasa (language learning) untuk bahasa kedua/bahasa asing dan ada juga yang menyebut pemerolehan bahasa (language acquisition) untuk bahasa pertama/bahasa Ibu. ${ }^{4}$ Dengan 2007), 11.

1 Baharuddin, Teori Belajar dan Pembelajaran (Yogyakarta: Ar-Ruzz Media,

2 Muhiyatul Huliyah, "Hakikat Pendidikan Anak Usia Dini," As-Sibyan : Jurnal Pendidikan Anak Usia Dini 1, no. 1 (2016): 60-71; Hasbullah Hasbullah, "Model Pengembangan Kurikulum PAUD," As-Sibyan : Jurnal Pendidikan Anak Usia Dini 1, no. 1 (2016): 21-28; Setiani dan Difla Nadjih, "Pembentukan Karakter Anak Usia Dini Melalui Pendidikan Agama Islam Di TK ABA Kalibulus Rogobangsan Bimomartani Ngemplak Sleman," Ulumuddin: Jurnal Ilmu-ilmu Keislaman 6, no. 2 ` (2016): 125-136.

3 Imroatun Imroatun, "Alternatif Media Pengembangan Literasi Baca Tulis Berbahasa Nasional bagi Siswa Raudlatul Athfal," in Al Hikmah Proceedings on Islamic Early Childhood Education, vol. 1 (Tuban: Program Studi PIAUD STAI Al Hikmah Tuban, 2018), 103-112.

4 Dadang Sunendar dan Wasid Iskandar, Strategi Pembelajaran Bahasa (Bandung: Rosdakarya, 2008), 77; Imroatun Imroatun, "Pembelajaran Huruf Hijaiyah 
demikian bahasa Arab bagi anak Indonesia adalah bahasa Asing. Bahasa Arab dapat dikuasai hanya dengan proses belajar yang dilakukan secara sengaja dan sadar, maka tepatlah kiranya istilah yang digunakan adalah "pembelajaran" (language learning). ${ }^{5}$

Bahasa sebagai alat komunikasi sangat diperlukan terlebih di era digital ini dimana koneksi pergaulan yang tak mengenal jarak dan batas. Demikian juga bahasa Arab, mengingat bahasa Arab merupakan salah satu bahasa internasional, bahasa Al-Qur'an dan bahasa agama Islam, ${ }^{6}$ yang digunakan sehari-hari dalam beribadah, maka bahasa Arab tentulah harus bermakna. Seiring dengan perkembangan teknologi dan kondisi pandemi gadget menjadi kebutuhan pokok bagi masyarakat bahkan anak usia dini. Anak-anak usia dini mahir mengoperasikan smartphone baik untuk belajar, game atau bermain media sosial. ${ }^{7}$ Media sosial inilah menjadi media komunikasi yang membawa dampak baik positif maupun negatif bagi anak. Salah satu dampak positifnya yaitu kesadaran anak maupun orang tua tentang pentingnya bahasa asing.

Kesadaran akan kebutuhan bahasa Arab pun mulai dirasakan oleh masyarakat kita dengan munculnya konten-konten lagu-lagu sholawat yang berbahasa Arab. Terbiasanya anak-anak mendengar dan kesadaran akan kebutuhan menguasai bahasa Arab inilah sebenarnya dapat menjadi faktor yang membawa kebermaknaan belajar bahasa Arab bagi anak. Kebermaknaan belajar ada yang berasal dari diri pelajar sendiri (instrinsik) ataupun dari luar (ekstrinsik). Tujuan kebermaknaan tidak dapat dicapai dengan mudah tanpa adanya kerjasama dari berbagai pihak dan segala aspek yang berperan didalamnya.

bagi Anak Usia Dini," in Proceedings of The 2nd Annual Conference on Islamic Early Childhood Education (Yogyakarta, 2017), 175-188.

5 Nginayatul Khasanah, "Pembelajaran Bahasa Arab Sebagai Bahasa Kedua (Urgensi Bahasa Arab Dan Pembelajarannya Di Indonesia)," An-Nidzam: Jurnal Manajemen Pendidikan dan Studi Islam 3, no. 2 (Desember 10, 2016): 39-54.

${ }^{6}$ Supriati H Rahayu et al., "Manajemen Mutu Layanan Ta'lim Quran lil Aulad (TQA) di Yayasan Team Tadarus 'AMM' Yogyakarta," Nuansa Akademik: Jurnal Pembangunan Masyarakat 5, no. 2 (Desember 26, 2020): 117-130.

7 Imroatun Imroatun et al., "Youtube as a Media for Strengthining Character Education in Early Childhood," in Journal of Physics: Conference Series, vol. 1779 (IOP Publishing Ltd, 2021), 012064; Imas Mastoah dan Zulaela MS, "Kendala Orang Tua Dalam Mendampingi Anak Belajar Pada Masa Covid 19 Di Kota Serang," As-Sibyan: Jurnal Pendidikan Anak Usia Dini 5, no. 2 (2020): 121-128. 
Dengan demikian, pembelajaran bahasa Arab yang bermakna (meaningful learning) tentunya sangat dibutuhkan sekali. Pada dasarnya pembelajaran akan lebih cepat untuk diterima oleh siswa jika mempunyai makna bagi mereka. Kebermaknaan dalam belajar terutama belajar bahasa Arab yang notabene sebagai bahasa asing tentunya lebih memerlukan usaha ekstra. Belajar bahasa Asing memang bukanlah hal yang mudah dan bukan hal yang sulit. Mudah atau sulitnya belajar bahasa itu tergantung dari individu pelajar sendiri, situasi pembelajaran, dan seluruh aspek pembelajaran.

Sayangnya, meskipun kesadaran akan kebutuhan mempelajari bahasa Arab mulai meningkat sebagaimana dinyatakan oleh orang tua anak akan tetapi pembelajaran bahasa Arab masih di klaim sebagai bahasa yang sulit dipelajari. Hal itu memang tidak bisa dipungkiri karena dari segi penulisan huruf arab dengan latin yang berbeda baik dari bentuk dan juga cara penulisannya. Maka pembelajaran Bahasa Arab seharusnya bukan sekedar penyampaian materi yang banyak dan tuntas tetapi penguasaan kemahiran (maharah) berbahasa Arab.

Penguasaan kemahiran (Maharah) berbahasa Arab yang meliputi maharah al-istima' (mendengar), maharah al-Kalam (berbicara) maharah al-Qiro'ah (membaca) dan maharah al-kitabah (menulis) dituntut adanya kebermaknaan. Kebermaknaan ini berarti bahwa proses belajar itu mempunyai makna tersendiri bagi anak (bukan hanya sekedar "asal belajar") yang nantinya akan dapat menjadi jembatan dalam keberhasilan pembelajaran dan pencapaian tujuan yang efektif.

Berbagai penelitian telah dilakukan dan dikaji guna mengatasi problematika yang muncul dalam pembelajaran bahasa Arab. Berbagai solusi ditawarkan seperti penggunaan metode, pemilihan dan penyajian materi, inovasi media dan lainnya. Pada umumnya metode dan media menjadi perhatian penting dalam kajian pengembangan pembelajaran. Ketidaktercapaian tujuan pembelajaran dianggap karena penggunaan metode dan media yang salah. Perlu disadari bahwa tidak ada istilah "salah" atau "benar" dalam pembelajaran akan tetapi " tepat” atau "kurang tepat”. Setelah melihat berbagai problematika pembelajaran bahasa Arab 
diberbagai tingkatan, salah satu problematika pembelajaran tersebut muncul karena kurang bermaknanya pembelajaran tersebut.

Pada penelitian sebelumnya memang sudah banyak dibahas tentang pendidikan anak usia dini dan ada beberapa penelitian yang memngkaji strategi pembelajaran bahasa Arab anak usia dini. Saidah Ramadhan dalam jurnal Utile mengkaji strategi pembelajaran bahasa Arab anak dan memfokuskan pada bahan ajar, cara penyampaian guru di pada tingkat ibtida' serta faktor pendukung dan penghambatnya. ${ }^{8}$ Senada dengan penelitian sebelumnya Nasrul Umam dan Utami budiyati juga mengkaji pembelajaran bahasa Arab anak usia dini berbasis nilai-nilai karakter dengan fokus kajian perencanaan dan langkah-langkah penyajian materi bahasa Arab. ${ }^{9}$

Pada kajian ini memfokuskan pada fenomena yang dilaksanakan oleh lembaga formal maupun nonformal yang mewadahi pendidikan anak usia dini dalam mencapai kebermaknaan. Kebermaknaan dalam pembelajaran menjadi hal penting dalam keberhasilan pembelajaran. Kebermaknaan dalam pembelajaran dalam teori belajar disebut dengan belajar bermakna (Meaningful Learning) diantaranya teori belajar bermakna Carl R. Rogers dan David Ausubel.

Belajar bermakna atau meaningful learning sebenarnya merupakan ide sentral dari teori David Ausubel yang tergabung dalam teori kognitif yang merupakan suatu proses dimana informasi baru dihubungkan dengan suatu aspek struktur pengetahuan (kognitif) yang relevan yang telah dipelajari dan diingat siswa (Advanced Organizer). ${ }^{10}$ Belajar bermakna juga dijadikan istilah oleh Carl P.Rogers yang tergabung

8 Saidah Ramadhan, "Strategi Pembelajaran Bahasa Arab Pada Anak Usia Dini," Utile: Jurnal Kependidikan 3, no. 2 (Desember 27, 2017): 180-189.

9 Nasrul Umam dan Utami Budiyati, "Pembelajaran Bahasa Arab Anak Usia Dini Berbasis Nilai-Nilai Karakter," Jurnal Warna 4, no. 1 (Juni 29, 2020): 46-64.

10 Nur Rahmah, "Belajar Bermakna Ausubel," Al Khwarizmi: Jurnal Pendidikan Matematika dan Ilmu Pengetahuan Alam 1, no. 1 (2013); Hidayatul Muamanah dan Suyadi, "Pelaksanaan Teori Belajar Bermakna David Ausubel Dalam Pembelajaran Pendidikan Agama Islam," Belajea; Jurnal Pendidikan Islam 5, no. 1 (Mei 22, 2020): 161-180. 
dalam teori belajar humanistic. ${ }^{11}$ Rogers dalam bukunya Freedom to Learn mengemukakan dua macam belajar: belajar tanpa makna adalah belajar yang hanya melibatkan otak tanpa menyertakan makna individual, sedangkan belajar bermakna melibatkan pengalaman langsung, pikiran dan perasaan; belajar dengan inisiatif sendiri dan menyertakan manusia secara utuh. Belajar bermakna bersifat meresap, ia akan mengubah secara cepat perilaku, sikap, bahkan kepribadian siswa. ${ }^{12}$ Belajar bermakna Rogers ini berbeda dengan pengertian belajar bermakna Ausubel. Rogers memaknai belajar bermakna (significant learning) sebagai kesesuaian antara apa yang dipelajari siswa dengan kebutuhan dan minatnya. ${ }^{13}$ Siswa menurutnya akan belajar dengan cepat apabila yang dipelajarinya memiliki arti bagi dirinya. ${ }^{14}$

Dengan demikian untuk mencapai kebermaknaan dalam pembelajaran bahasa Arab diperlukan strategi yang tepat untuk menerapkan metode, penyampaian dan pemilihan materi maupun media. Strategi tersebut tentunya perlu dilakukan oleh Taman Kanak-kanak (TK) dan Taman Pendidikan Al-Qur'an (TPA) sebagai bagian dari lembaga pendidikan anak usia dini.

\section{B. Metode}

Penelitian ini merupakan penelitian kualitatif untuk memperoleh gambaran fenomena yang mendalam dan terinci mengenai strategi mencapai kebermaknaan pembelajaran bahasa Arab pada anak usia dini baik pada lembaga pendidikan Islam baik formal maupun nonformal dalam situasi natural. Dalam hal ini Taman Kanak-kanak (TK) dan Taman Pendidikan Al-Qur'an (TPA/TPQ). Pengumpulan data dilakukan dengan observasi yang dilakukan peneliti sebagai instrumen primer terkait fenomena, aktivitas pembelajaran serta wawancara kepada guru,

11 Farah Dina Insani, "Teori Belajar Humanistik Abraham Maslow Dan Carl Rogers Serta Implikasinya Dalam Pembelajaran Pendidikan Agama Islam," As-Salam: Jurnal Studi Hukum Islam \& Pendidikan 8, no. 2 (Desember 27, 2019): 209-230.

12 Erni Murniarti, Pengertian, Prinsip, Bentuk Metode Dan Aplikasinya Dari Teori Belajar Dari Pendekatan Konstruktivisme Dan Teori Belajar Person-Centered Carl Rogers (Jakarta: Fakultas Keguruan dan Ilmu Pendidikan, Universitas Kristen Indonesia Jakarta, 2020).

13 Insani, "TEORI"

14 Ibid. 
ustadz/dzah maupun peserta didik di TK maupun TPA. Adapun analisisnya melalui tiga tahapan yaitu reduksi data, penyajian data dan penarikan kesimpulan.

\section{Strategi Mencapai Kebermaknaan Dalam Pembelajaran Bahasa Arab Pada Anak Usia Dini}

Sebagaimana telah dipaparkan sebelumnya bahwa anak usia dini adalah anak usia o-6 tahun. Anak usia dini merupakan investasi bangsa maka pendidikan harus dimulai sejak usia dini. ${ }^{15}$ Anak pada usia ini merupakan anak usia sekolah PAUD atau TK. Ada beberapa karakteristik dari anak-anak usia dini yaitu Pada penelitian ini diambil anak-anak di beberapa TK Muslimat sebagai TK yang berbasis keagamaan. Anak-anak TK muslimat tersebut juga mengikuti pendidikan nonformal di TPA untuk memenuhi kebutuhan anak-anak dalam mempelajari agama Islam.

Sudah menjadi pemahaman umum baik bagi guru maupun orang tua usia dini adalah masa yang keemasan dan tidak akan terulang. Masa ini juga adalah masa istimewa untuk belajar agar anak-anak mendapatkan pengalaman, pengetahuan yang kokoh dan akan berpengaruh pada tumbuh kembangnya di masa selanjutnya. Dengan demikian agar masa keemasan ini tidak sia-sia maka anak diberikan kesempatan untuk memperoleh pembelajaran yang memadai sesuai dengan karakteristik anak usia dini diantaranya memiliki rasa ingin tahu yang besar, pribadi yang unik, suka berfantasi dan berimajinasi, masa paling potensial untuk belajar, menunjukkan sikap egosentris, memiliki rentang daya konsentrasi yang pendek, sebagai bagian dari makhluk sosial. ${ }^{16}$

Karakteristik anak usia dini tersebut akan membawa prinsip pembelajaran yang berbeda dengan dengan jenjang selanjutnya seperti belajar sambil bermain atau bermain sambil belajar. Prinsip pembelajaran anak usia dini bisa dijadikan sebagai acuan dalam pelaksanaan pembelajaran di TK/TPA yang berarti berlaku juga untuk pembelajaran

15 Slamet Suyanto, "Pendidikan Karakter untuk Anak Usia Dini," Jurnal Pendidikan Anak 1, no. 1 (Februari 4, 2015): 1-10; Huliyah, "Hakikat"

${ }^{16}$ Husnuzziadatul Khairi, "Karakteristik Perkembangan Anak Usia Dini Dari o-6 Tahun," Jurnal Warna 2, no. 2 (2018): 15-28. 
bahasa Arab bagi anak usia dini dimana anak usia dini belajar anak belajar dari apa yang dilihat, didengar, dan dirasakannya. ${ }^{17}$

Pembelajaran bahasa Arab merupakan pembelajaran bahasa Asing. Bahasa Arab dapat dikuasai hanya dengan proses belajar yang dilakukan secara sengaja dan sadar, maka tepatlah kiranya istilah yang digunakan adalah "pembelajaran" (language learning). Pembelajaran bahasa Arab sebagai bahasa asing dan dengan segala keunikan bahasa Arab, maka khususnya bagi anak usia dini akan menimbulkan problematika.

Secara umum problematika pembelajaran bahasa Arab berasal dari bahasa Arab itu sendiri (problematika linguistik) seperti bunyi/phonetik, penulisan/morfologi, gramatika dan semantik dan juga disebabkan oleh problematika Non Linguistik seperti: Problematika SosioKultural, Sejarah, dan Problematika yang terdapat pada Guru atau peserta didik itu sendiri dalam proses pembelajaran bahasa Arab. ${ }^{18}$ Berbagai problematika pembelajaran bahasa Arab bagi anak usia dini Bagi anak usia dini belajar bahasa Arab sebagai bahasa asing menjadi perhatian yang penting. Dikarenakan pembelajaran melibatkan beberapa komponen diantaranya guru, materi, metode dan media maka disini guru memegang peranan penting untuk mencapai keberhasilan pembelajaran. ${ }^{19}$

Keberhasilan pembelajaran anak usia dini juga mempertimbangkan kesesuaian tujuan dengan kebutuhan riil anak. ${ }^{20}$ Kebutuhan anak berbeda sesuai dengan perkembangannya. Selain memperhatikan tahap perkembangan anak guru/ustad/ustadzah juga memperhatikan kebutuhan anak sesuai dengan usianya. Kebutuhan dan perkembangan anak yang umum pada usia ini terhadap bahasa adalah bahasa sebagai alat komunikasi dan bekal belajar.

17 Ika Budi Maryatun, "Peran Pendidik PAUD Dalam Membangun Karakter Anak," Jurnal Pendidikan Anak 5, no. 1 (Juni 19, 2016): 747-752.

18 Abdul Aziz bin Ibrahim Al-Ashili, Asasiyat ta'lim al-Lughat al-Arabiyat liAnnathiqin bi al-Lughatil ukhra (Riyad: Jami'ah Ummul Qura, 1423), 143.

19 Nurul Fatihah dan Difla Nadjih, "Hubungan Pendidik Dan Terdidik Dalam AlQuran," Ulumuddin: Jurnal Ilmu-ilmu Keislaman 7, no. 2 (2017): 73-86; Toto Hermawan, "Pengaruh Kemampuan Bertanya Terhadap Hasil Belajar," Intersections 1, no. 1 (2016).

20 Dadan Suryana, Pendidikan Anak Usia Dini (Stimulasi \& Aspek Perkembangan Anak) (Jakarta: Kencana, 2016), 257-258. 
Diantara lembaga pendidikan yang mewadaih anak usia dini yaitu Taman Kanak-kanak (TK) sebagai lembaga pendidikan formal dan Taman Pendidikan Al-Qur'an (TPA) sebagai lembaga pendidikan nonformal. dalam penelitian ini TK yang dimaksud adala TK Muslimat NU dan TPA dilingkungan TK berada. Bahasa arab di TK muslimat yang notabene adalah lembaga pendidikan formal berbasis keagamaan dan TPA sebagai lembaga pendidikan keagamaan nonformal, pembelajaran bahasa Arab selain mempertimbangkan kebutuhan sebagai alat komunikasi juga kebutuhan untuk belajar agama.

Berdasarkan hasil penelitian didapatkan bahwa mayoritas TK Muslimat atau TPA berusaha menanamkan pengetahuan bahasa Arab pada peserta didiknya sebagai bekal dasar bagi anak-anak. Demikian itu dikarenakan kesadaran akan pentingnya bahasa Arab bagi anak didiknya sebagai umat Islam untuk lebih memahami ajaran agamanya. Bahasa Arab adalah bahasa Al-Qur'an. Dalam belajar Al-Qur'an bahasa Arab merupakan syarat mutlak yang harus dikuasai, demikian halnya dengan belajar bahasa Al-Qur'an berarti belajar bahasa Arab. ${ }^{21}$ Selain itu, bahasa Arab termasuk salah satu bahasa yang banyak digunakan di dunia, karena banyak yang menggunakannya dan menjadi bahasa internasional. Maka tidak berlebihan jika pembelajaran bahasa Arab perlu mendapatkan penekanan dan perhatian mulai dari usia dini.

Faktor-faktor tersebut yang menjadi perhatian guru di TK agar anak-anak mengenal, memahami dan menguasai maharah bahasa Arab sebagai bekal mengusai maharah bahasa Arab di jenjang selanjutnya. Hal serupa juga dilakukan di TPA sebagai lembaga pendidikan agama nonformal. di beberapa TPA terlepas dari berbagai metode yang digunakan baik qiro,ati maupun iqro' disisipkan materi bahasa Arab tersendiri dengan tujuan anak-anak terbiasa dengan bahasa Arab karena bahasa Arab sebagai Bahasa al-Qur'an serta pengusaan maharah bahasa arab tentu membawa pengaruh pada pembelajaran Al-Qur'an.

${ }^{21}$ Nandang Sarip Hidayat, "Problematika Pembelajaran Bahasa Arab," An-Nida' 37, no. 1 (Juni 2, 2012): 82-88. 
Materi bahasa Arab yang disampaikan di TK Muslimat adalah materi bahasa sederhana pengenalan kosakata (mufrodat). Materi mufrodat yang dipilih adalah mufrodat sederhana yang dibutuhkan oleh anak dalam kehidupan sehari-hari, yang berkesan sesuai karakteristik anak usia tersebut. Mufrodat pun disampaikan kepada anak dengan nyanyian, bermain peran atau cerita sebagai metode pembelajarannya atau menggunakan gambar berwarna-warni, model, video atau lainnya visual, audio maupun audiovisual.

Materi bahasa Arab yang diberikan kepada anak dikelompokan dalam beberapa tema. Masing-masing tema bahasa Arab tersebut disampaikan oleh guru kepada anak didik dengan menggunakan beberapa metode dan media. Materi bahasa yang diajarkan di tingkat TK ini yaitu tema yang berarti dan dibutuhkan anak seperti tentang bilangan/angka, anggota tubuh, arah, warna, peralatan sekolah, nama-nama tanaman dan binatang, buah-buahan, makanan dan benda-benda yang ada di sekitar anak.

Adapun bernyanyi adalah metode yang sering digunakan oleh guru untuk menanamkan kebermaknaan pada anak dengan menggunakan media visual seperti gambar atau model (benda konkret). Dengan nyanyian anak merasa pembelajaran menyenangkan dan tanpa paksaan. Pemilihan materi metode dan media yang dilakukan oleh guru TK ini sadar atau tidak sadar tujuannya yaitu agar materi bahasa Arab yang diperoleh anak bermakna sesuai dengan kebutuhan anak sehingga membekas dan tidak mudah dilupakan oleh anak.

Tidak jauh berbeda dengan taman kanak-kanak, materi bahasa Arab di TPA selain menjadi satu kesatuan dalam metode yang dipakai seperti Iqro', Qiro'ati, dan Baghdady, materi bahasa Arab lainnya juga diajarkan kepada anak. Dengan prinsip yang sama dengan di TK bahwa materi yang diajarkan kepada siswa adalah materi yang bermanfaat dan dibutuhkan oleh anak, maka materi tersebut biasanya berupa mufrodat seperti angka/bilangan,mufrodat sederhana dalam hadits-hadits pendek yang digunakan anak dalam kehidupan sehari-harinya seperti annadzafatu minal iman dan lainnya. Selain hadits-hadits juga materi 
bahasa Arab diajarkan lewat do'a-do'a dengan menerjemahkannya. Disamping materi-materi tambahan itu, materi bahasa Arab yang tercantum dalam materi Qira'atul Qur'an yaitu contoh-contoh bacaan yang mempunyai arti dan mudah diingat dalam struktur kognitif anak. Adapun metode dan media yang digunakan di TPA sedikit berbeda dengan di TK. Jika d TK metode lebih banyak menggunakan nyanyian dan media yang bersifat audio, visual, atau audio visual maka di TPA metode yang sering digunakan adalah metode langsung (mubasyarah) dengan media sederhana menggunakan panan tulis atau buku sumber.

Pemilihan materi, metode dan media yang dilakukan guru/ustad/ustadzah itu semua mempunyai satu tujuan yaitu mencapai kebermaknaan dalam pembelajaran bahasa Arab sehingga materi yang diperoleh anak dapat digunakan dan memang dibutuhkan oleh anak baik dalam kehidupan sehari-hari, mempelajari agama, maupun untuk bekal mempelajari bahasa Arab pada jenjang selanjutnya.

Hal tersebut sejalan dengan teori belajar humanistik Rogers bahwa Guru menghubungkan pengetahuan akademik ke dalam pengetahuan terpakai atau Experiential Learning yang menunjuk pada pemenuhan kebutuhan dan keinginan siswa. ${ }^{22}$ Menurut Rogers yang terpenting dalam proses pembelajaran adalah pentingnya guru memperhatikan prinsip pendidikan dan pembelajaran, yaitu; “1)Menjadi manusia berarti memiliki kekuatan yang wajar untuk belajar. Siswa tidak harus belajar tentang halhal yang tidak ada artinya. 2) Siswa akan mempelajari hal-hal yang bermakna bagi dirinya. 3) Pengorganisasian bahan pengajaran berarti mengorganisasikan bahan dan ide baru sebagai bagian yang bermakna bagi siswa. 4)Belajar yang bermakna dalam masyarakat modern berarti belajar tentang proses."

Namun lebih luas lagi, kita bisa mengartikan meaningful learning sebagai belajar bermakna bagi diri siswa baik secara kognitif, afektif atau psikomotorik. Diperhatikannya seluruh variabel dalam pendidikan meminjam bahasa Bobby De Potter bisalah kita sebut dengan orkestrasi. 109.

${ }_{22}$ Tim Penyusun, Psikologi Pendidikan (Yogyakarta: UNY Press, 2006), 108- 
Orkestrasi itu meliputi segala hal yang berkaitan dengan pembelajaran. Diantaranya adalah materi belajar, persiapan atau rancangan pengajaran, orkestrasi keterampilan, penyampaian dan seterusnya. ${ }^{23}$

Menurut Ausubel belajar seharusnya merupakan asimilasi yang bermakna bagi siswa. Materi yang dipelajari diasimilasikan dan dihubungkan dengan pengetahuan yang telah dimiliki siswa dalam bentuk struktur kognitif. Jadi selama belajar bermakna berlangsung, informasi baru diasimilasikan dengan subsumer yang relevan didalam struktur kognitif. Belajar bermakna yang baru, lebih jadi menyebabkan pertumbuhan dan perubahan subsumers. Penyimpanan dan asimilasi informasi dari dalam otot, bersama dengan informasi yang diterima dari luar penting di dalam belajar keterampilan dengan perangsang afektif yang dikenal sebagai emosi atau belajar afektif. Belajar afektif berhubungan dengan belajar keterampilan dan belajar kognitif. ${ }^{24}$

Jadi, kita dapat belajar mencintai bahasa karena mempunyai simpanan afektif positif terhadap bahasa dan membenci bahasa karena memiliki simpanan afektif negatif terhadap bahasa. Maka motivasi dan minat siswa juga mempengaruhi kebermaknaan belajar. Maka untuk menumbuhkan motivasi dan minat belajar bahasa Arab kiranya dimulai sejak dini dengan menanamkan dan menumbuhkan simpanan afektif positif terhadap bahasa Arab seperti menanamkan bahwa bahasa Arab itu Mudah, menyenangkan, dan bermanfaat.

Berdasarkan pemaparan diatas maka TK Muslimat dan TPA yang ada dilingkungan TK Muslimat tersebut berada mempunyai peran penting yang saling berkaitan dalam pembelajaran bahasa Arab bagi khususnya anak usia dini. Pencapaian kebermaknaan dalam pembelajaran bahasa Arab pada anak usia dini akan lebih maksimal dengan adanya keterkaitan antara pembelajaran di TK maupun di TPA meskipun pada asalnya antara kedua lembaga tersebut tidak bersama-sama dalam merencanakan dan melaksanakan strategi pembelajarannya.

23 Abdurrahman, Meaningful Learning: Re-Invensi Kebermaknaan Pembelajaran (Yogyakarta: Pustaka Pelajar, 2007), 133.

24 Nazri Syakur, Dari Pendekatan Komunikatif Menuju Komunikatif Kambiumi: Modul Perkuliahan Psikolinguitik (Yogyakarta: PBA UIN Suka, 2009), 219. 
Terlepas dari semua strategi baik materi, metode maupun media guru/ustadz/ustadzah bagi pendidikan anak usia dini diluar lingkungan keluarga (orangtua) mempunyai peranan penting. Mengutip maqalah dari K.H. Imam Zarkasyi dan K.H. Hasan Abdullah Sahal (Pondok Modern Darussalam Gontor) bahwa at-thariqah ahammu mina-l-maddah, wa almudarris ahammu mina-t-thariqah, wa ruhu-l-mudarris ahammu minal-mudarris nafsihi. Hal ini berarti bahwa guru mempunyai peran penting dalam mencapai keberhasilan pembelajaran disamping metode dan materi. Hal ini berarti bahwa strategi guna mencapai kebermaknaan pembelajaran bahasa Arab tidak lepas dari peran guru/ustadz/ustadzah baik di TK maupun TPA.

\section{Penutup}

Anak usia dini merupakan fase keemasan atau sering disebut "golden age". Fase ini merupakan fase yang penting tumbuh kembang anak dalam segala aspek salah satunya aspek kognitif. Usia dini dimulai sejak o- 6 tahun. Pada masa ini anak mengalami pertumbuhan dan perkembangan jasmani, rohani, psikis, fisik, dan kognitifnya. Pada usia dini ini anak menerima rangsangan dan belajar merespon stimulus yang diterima baik perilaku maupun tutur kata, dalam hal ini adalah bahasa. Anak-anak memperoleh bahasa pertama dengan cara menirukan sedangkan bahasa kedua diperoleh dengan cara mempelajari secara sengaja melalui proses pembelajaran. Bahasa Arab sebagai bahasa asing bagi anak Indonesia, dalam pembelajarannya ditemukan berbagai problematika yang harus dicarikan solusi.

Pada hakekatnya pembelajaran tidaklah sekedar pencapaian prestasi akan tetapi pencapaian tujuan yang optimal. Salah satunya yaitu mencapai kebermaknaan belajar. Kebermaknaan pembelajaran perlu ditempuh dengan berbagai strategi. Guru/ustadz/ustadzah di TK/TPA sebagai lembaga pendidikan anak usia dini formal dan nonformal memegang peranan penting dalam menerapkan strategi tersebut. Kebermaknaan pembelajaran bahasa Arab anak usia dini bisa dicapai dengan penerapan strategi yang tepat diantara dengan pemilihan materi, media, dan metode yang tepat sesuai dengan tahap perkembangan anak 
usia dini yaitu belajar sambil bermain. Materi yang disajikan baik di TK maupun TPA adalah materi dasar berupa pengenalan kosakata yang ditemukan, dibutuhkan dan digunakan oleh anak dalam kehidupannya. Materi tersebut baik di TK maupun TPA disajikan dengan metode bermain dan bernyanyi menggunakan media audio visual yang menarik dan bendabenda konkret sesuai dengan usia anak. Penyesuaian materi, metode dan media yang digunakan di TK/TPA sesuai dengan usia dan perkembangan anan anak akan mempengaruhi kebermaknaan belajar. Kebermaknaan tersebut mengacu pada teori belajar bermakna kognitif (David Ausubel) dan teori belajar bermakna humanistik (Rogers).

\section{Daftar Pustaka}

Abdurrahman. Meaningful Learning: Re-Invensi Kebermaknaan Pembelajaran. Yogyakarta: Pustaka Pelajar, 2007.

Al-Ashili, Abdul Aziz bin Ibrahim. Asasiyat ta'lim al-Lughat al-Arabiyat li-Annathiqin bi al-Lughatil ukhra. Riyad: Jami'ah Ummul Qura, 1423 .

Baharuddin. Teori Belajar dan Pembelajaran. Yogyakarta: Ar-Ruzz Media, 2007.

Fatihah, Nurul, dan Difla Nadjih. "Hubungan Pendidik Dan Terdidik Dalam Al-Quran.” Ulumuddin: Jurnal Ilmu-ilmu Keislaman 7, no. 2 (2017): 73-86.

Hasbullah, Hasbullah. "Model Pengembangan Kurikulum PAUD." AsSibyan : Jurnal Pendidikan Anak Usia Dini 1, no. 1 (2016): 21-28.

Hermawan, Toto. "Pengaruh Kemampuan Bertanya Terhadap Hasil Belajar.” Intersections 1, no. 1 (2016).

Hidayat, Nandang Sarip. "Problematika Pembelajaran Bahasa Arab." AnNida' 37, no. 1 (Juni 2, 2012): 82-88.

Huliyah, Muhiyatul. "Hakikat Pendidikan Anak Usia Dini." As-Sibyan : Jurnal Pendidikan Anak Usia Dini 1, no. 1 (2016): 60-71.

Imroatun, Imroatun. "Alternatif Media Pengembangan Literasi Baca Tulis Berbahasa Nasional bagi Siswa Raudlatul Athfal.” In Al Hikmah Proceedings on Islamic Early Childhood Education, 1:103-112. Tuban: Program Studi PIAUD STAI Al Hikmah Tuban, 2018.

- - . "Pembelajaran Huruf Hijaiyah bagi Anak Usia Dini." In Proceedings of The 2nd Annual Conference on Islamic Early Childhood Education, 175-188. Yogyakarta, 2017.

Imroatun, Imroatun, Faizatul Widat, Mohammad Fauziddin, Siti Farida, Siti Maryam, dan Zulaiha. "Youtube as a Media for Strengthining Character Education in Early Childhood." In Journal of Physics: Conference Series, 1779:012064. IOP Publishing Ltd, 2021.

Insani, Farah Dina. "Teori Belajar Humanistik Abraham Maslow Dan Carl Rogers Serta Implikasinya Dalam Pembelajaran Pendidikan Agama Islam.” As-Salam: Jurnal Studi Hukum Islam \& Pendidikan 8, no. 
2 (Desember 27, 2019): 209-230.

Khairi, Husnuzziadatul. "Karakteristik Perkembangan Anak Usia Dini Dari o-6 Tahun.” Jurnal Warna 2, no. 2 (2018): 15-28.

Khasanah, Nginayatul. "Pembelajaran Bahasa Arab Sebagai Bahasa Kedua (Urgensi Bahasa Arab Dan Pembelajarannya Di Indonesia).” AnNidzam : Jurnal Manajemen Pendidikan dan Studi Islam 3, no. 2 (Desember 10, 2016): 39-54.

Maryatun, Ika Budi. "Peran Pendidik PAUD Dalam Membangun Karakter Anak.” Jurnal Pendidikan Anak 5, no. 1 (Juni 19, 2016): 747-752.

Mastoah, Imas, dan Zulaela MS. "Kendala Orang Tua Dalam Mendampingi Anak Belajar Pada Masa Covid 19 Di Kota Serang." As-Sibyan: Jurnal Pendidikan Anak Usia Dini 5, no. 2 (2020): 121-128.

Muamanah, Hidayatul, dan Suyadi. "Pelaksanaan Teori Belajar Bermakna David Ausubel Dalam Pembelajaran Pendidikan Agama Islam.” Belajea; Jurnal Pendidikan Islam 5, no. 1 (Mei 22, 2020): 161-180.

Murniarti, Erni. Pengertian, Prinsip, Bentuk Metode Dan Aplikasinya Dari Teori Belajar Dari Pendekatan Konstruktivisme Dan Teori Belajar Person-Centered Carl Rogers. Jakarta: Fakultas Keguruan dan Ilmu Pendidikan, Universitas Kristen Indonesia Jakarta, 2020.

Rahayu, Supriati H, Hilman Haroen, TW Budiutomo, Nginayatul Khasanah, dan Nuryati. "Manajemen Mutu Layanan Ta'lim Quran lil Aulad (TQA) di Yayasan Team Tadarus 'AMM' Yogyakarta." Nuansa Akademik: Jurnal Pembangunan Masyarakat 5, no. 2 (Desember 26, 2020): 117-130.

Rahmah, Nur. "Belajar Bermakna Ausubel." Al Khwarizmi: Jurnal Pendidikan Matematika dan Ilmu Pengetahuan Alam 1, no. 1 (2013).

Ramadhan, Saidah. "Strategi Pembelajaran Bahasa Arab Pada Anak Usia Dini." Utile: Jurnal Kependidikan 3, no. 2 (Desember 27, 2017): 180-189.

Setiani, dan Difla Nadjih. "Pembentukan Karakter Anak Usia Dini Melalui Pendidikan Agama Islam Di TK ABA Kalibulus Rogobangsan Bimomartani Ngemplak Sleman.” Ulumuddin: Jurnal Ilmu-ilmu Keislaman 6, no. 2 ' (2016): 125-136.

Sunendar, Dadang, dan Wasid Iskandar. Strategi Pembelajaran Bahasa. Bandung: Rosdakarya, 2008.

Suryana, Dadan. Pendidikan Anak Usia Dini (Stimulasi \& Aspek Perkembangan Anak). Jakarta: Kencana, 2016.

Suyanto, Slamet. "Pendidikan Karakter untuk Anak Usia Dini." Jurnal Pendidikan Anak 1, no. 1 (Februari 4, 2015): 1-10.

Syakur, Nazri. Dari Pendekatan Komunikatif Menuju Komunikatif Kambiumi: Modul Perkuliahan Psikolinguitik. Yogyakarta: PBA UIN Suka, 2009.

Tim Penyusun. Psikologi Pendidikan. Yogyakarta: UNY Press, 2006.

Umam, Nasrul, dan Utami Budiyati. "Pembelajaran Bahasa Arab Anak Usia Dini Berbasis Nilai-Nilai Karakter.” Jurnal Warna 4, no. 1 (Juni 29, 2020): 46-64. 
Nginayatul Khasanah 